\title{
Revealed Comparative Advantage: An Analysis of Exports of Rwanda
}

\author{
Mayank Gupta ${ }^{1}$, Harish Kumar $^{2}$ \\ ${ }^{1}$ (Day Scholar, Shri Ram College of Commerce, University of Delhi, New Delhi) \\ ${ }^{2}$ (Assistant Professor, Shri Ram College of Commerce, University of Delhi, New Delhi)
}

\begin{abstract}
The paper undertakes a detailed analysis of Revealed Comparative Advantage of the exports of $R$ wanda. The objective of the research is to understand the Rwanda's pattern of trade; to identify a change in this pattern over the period of study; in support of the policies and strategies, to identify areas for improvement. Rwanda is primarily an agrarian economy where people have been dependent on country's natural endowments for subsistence. A large population is still employed in the agricultural sector. The revealed comparative advantage lies in primary products. There has been little change in the composition of exports. The Standard Balassa Revealed Comparative Advantage Index (BRCAI) has been used for analysis. Rwanda' RCAI in its otherwise primary exports product lines has been declining owing to increasing pressure from the supply side. Intense competition from other exporting economies has made Rwandan exports uncompetitive. The country needs to invest in research and development, technological advancements and Education in order to boost output and exports. The government needs to push reforms in industrial sector and open up the economy for private players in more industries, especially agro-processing and leather-goods.
\end{abstract}

Keywords: Revealed Comparative Advantage, Balassa Index, Rwanda, Namibia, Export Competitiveness

\section{Introduction}

Located in eastern Africa, Republic of Rwanda, or normally Rwanda, is a small country which holds strategic interests for various parties today. The country boasts a plethora of qualities which compel us to study it in detail. Spanning across $26,338 \mathrm{sq}$. $\mathrm{km}$ of area, Rwanda is home to approximately 13 million people. After the Genocide in 1994, the country embarked upon a journey of development which saw unprecedented level of dedication and support from the end of all major stakeholders, especially the Rwandan Government.The Government, after the genocide, thrived to resurrect the economy. From identification of strategic sectors to implementation of various plans and policies successfully, the economy has achieved its growth targets with pride. It is a landlocked country sharing its boundaries with Burundi, Democratic Republic of Congo, Tanzania and Uganda. The country is rich in gold, Cassiterite (tin ore), Wolframite (tungsten ore), methane reserves, and hydropower and arable land. Over $93 \%$ of its population is less than 55 years old. $74.5 \%$ of its land is used for agriculture. Agriculture provides employment and subsistence to $90 \%$ of the population while its share in the GDP is just 34.6\%. Its GDP has grown at an average rate of 7-8\% since 2003 and inflation has dropped to single digits. $28.8 \%$ of its population lives in urban areas and rate of urbanization is $6.43 \%$. The government has been successful to make provision of basic facilities for a majority of population after the genocide. The literacy rate is $70.5 \%$. Tourism, minerals, coffee and tea are the main sources of foreign exchange earnings today. Mining, Construction, Agriculture are the cornerstones of its economy. The government has been making sincere efforts to make these and other related sectors more lucrative for foreign investments and improve country's socioeconomic situation. Rwanda displays rare qualities to become a major economy in the future based on its proactive, strong and stable government, rising literacy level and urbanization, falling infant and maternal mortality rate, poverty and death rate. Its entry in the East African Community (EAC) has opened new opportunities.

Rwanda has been active in international trade since a long time. The country has been exporting cash crops, primarily coffee and tea since colonial times and still depends on the same for a large chunk of its foreign exchange earnings. Over the years, the product lines and categories that Rwanda exports in have expanded. Though it is primarily an agrarian economy, it has started to export semi-processed and processed products as well. With growing inter-dependence among all the countries in the world, the role of each one of them matters. So, it becomes imperative to understand how Rwanda stands in Exports and where does its specialization lie. The study is organized in the following sequence. Starting with introduction, a selective review of literature on revealed comparative advantage and its application is done, especially in the Rwandan and African context. Next, the objectives of study and methodology used have been specifically and precisely described. In chapter 4 , the analysis of comparative advantage of Rwandan Exports is undertaken and interpretation is done. Finally, in the last chapter, conclusions are drawn and recommendations are given. 


\section{Literature Review}

International Trade is defined as the exchange of capital, goods and services across international borders or territories. It has been prevalent since a millennium. Consistent with the way in which nations traded with each other over time, economists developed theories to explain the mechanisms of global trade. The phenomenon has evolved considerably over time. Ranging from the classical theory which talked about global trade mechanics from a country's perspective, there are modern theories which talk about international trade from a firm's perspective. But a basic question which intrigues us is 'why do countries trade?' Trading across borders provides various benefits. Adam Smith, in his book 'The wealth of Nations', interpreted the meaning of 'Value' in two ways:

1) Exchange value

2) Consumption value

He propounded that some commodities possess exchange value, which make them of little use for consumption but adept for being used as a medium of exchange. On the other hand, other commodities possess consumption value, which possess utility for consumption but are incapable of being used for exchange. International trade helps countries engaging in it to buy goods which hold consumption value in exchange of goods which hold exchange value. Countries trade because of relative differences in prices of the same good across different parts of the world. The relevance and importance of International Trade has increased remarkably over the last two centuries, especially since the Industrial Revolution and can be gauged from the growth in absolute value of exports over time. The figure 1 below shows the value of exports of goods and services from 1960 to 2015. From US\$155 Billion in 1960, the value has increased to US\$21.27 Trillion, at a compound annual growth rate of $9.36 \%$.

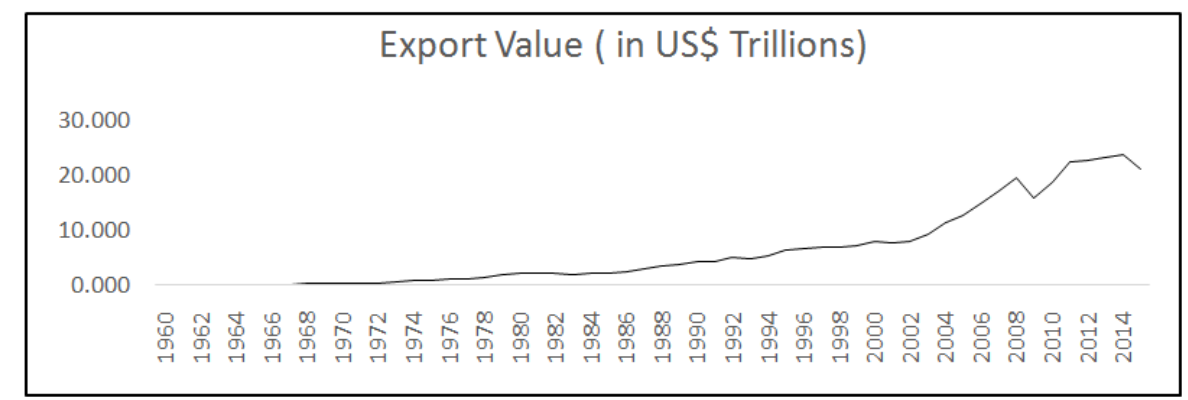

Figure 1: Global Export Value Growth, 1960-2015

Further, a measure to look into the importance of International trade is to look at the share of traded goods in relation to the size of the world economy. The share of exports in world GDP has increased from $12 \%$ in 1960 to near $30 \%$ in 2015 . Thus, trade is rising not only in absolute terms but also in relation to the size of the world economy, hence gaining more importance.

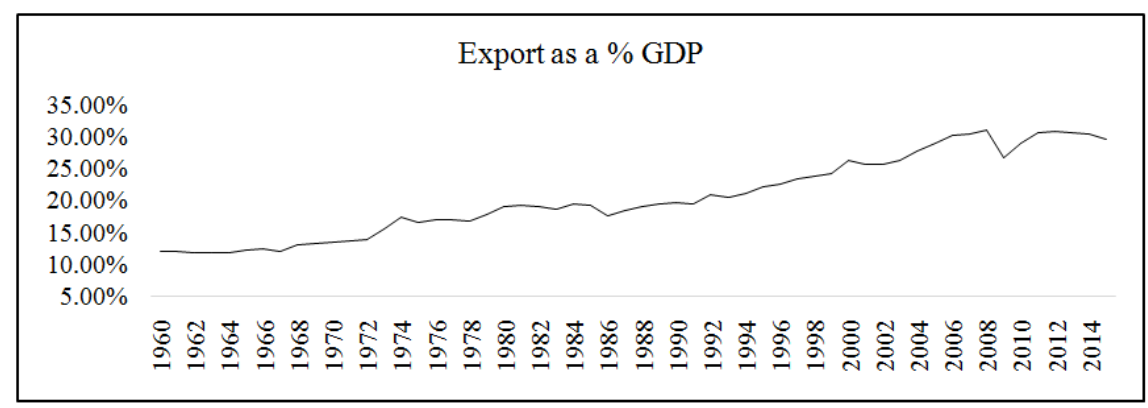

Figure 2: Global Export of Goods \& Services as a \% of GDP, 1960-2015

The concept which suggests what an economy should export and import was coined for the first time in the $18^{\text {th }}$ Century by Adam Smith when he talked about 'Absolute Advantage' in his book 'The Wealth of Nations'. He advocated the idea of exporting those goods in which an economy has absolute advantage, i.e. goods which the economy can produce at lesser cost of production than rest of the world. It advocates the phenomenon that each country shall eventually shift its limited factors of production, assumed to be labour, to produce those goods and services that it specializes in. Later, David Ricardo came up with a new concept in his book 'The Principles of Political Economy and Taxation' where he supported the idea of exporting only those goods in which an economy enjoys 'Comparative' Advantage. The idea of comparative advantage lied in 
opportunity cost of producing one commodity in place of another. If one country's opportunity cost of producing a commodity, say A, in terms of loss of production of another commodity, say B, is less than that of the other country, then it should export good A and the other country should import it. Countries with technological prowess in production of a certain commodity shall require lesser unit of inputs to produce an additional unit of its output than the other country. This is the epitome of the term 'Revealed Comparative Advantage'. It is an arithmetic Equation which was given by Balassa(1965). Thus, Revealed Comparative Advantage reckons the magnitude of comparative advantage that a country enjoys in exports of various goods.

In their Study, Divaries C. Jaravaza \& Macleans Mzumara (2013)tried to find the comparative advantage of Rwanda in different product lines. Their primary Objective was to assess whether membership of Common Market for Eastern and Southern Africa (COMESA) helped Rwanda increase its comparative advantage in the products it exports to its COMESA partners. They used RCA as Wu and Chen (2004) had put forward because it shows relative comparative advantage of the same product in various countries and relative competitiveness of various products within the same country. They concluded that Rwanda benefitted from intra-COMESA trade and trade with global partners, and recommended that Rwanda should continue to export goods it has comparative advantage in. Rwanda has very few products it specializes in. the EAC member states are gaining from international trade as propagated by Ricardo (1817)and Heckscher-Ohlin. They recommended that the East African Community should continue discussing with the Southern African Development Community (SADC) and Common Market for Eastern and Southern Africa (COMESA) for possible merger. That way the community could ensure trade creation rather than trade diversion considering the limited number products in which the member states have comparative advantage. Mphumuzi Sukati (2016) studied the RCA of COMESA Members in common agricultural commodities to search for opportunities to set up agro-processing industries in these countries. The objective of his research was to determine the level of agro-processing in the region and identify key commodities the member countries could focus on to set up agro-processing units. He used the Standard Balassa (1965) Index for the analysis. However, he normalized the analysis using the approach proposed by Laursen (2000). There is upper bound for products with a revealed comparative advantage but a lower bound of 0 for products with revealed comparative disadvantage. The approach was:-

$$
R C A_{k}^{i}-1 / R C A_{k}^{i}+1
$$

On the basis of data analysed (data from 2005 to 2013), it was found that Rwanda had high RCA in live animals, raw hides and skins, leather and unprocessed coffee, and the country could foray into industries that use these commodities as primary raw material for production.

Balassa \& Noland (1989) studied the revealed comparative advantage of Japan and the United States. with the objective of identifying changes in specialization of these two economies in product categories differentiated on the basis of human skills involved. The authors used the standard RCAI coupled with the net exports revealed comparativeadvantage Index. RCAI data was collected for 4-years intervals starting from 1967 till 1983. The product categories were classified into: Primary Goods, Unskilled-Labour Intensive Goods, Humans-Capital Intensive Goods and Physical Capital Intensive Products. Their Study revealed that during the period of study, Japan ratcheted up towards becoming a more human capital intensive industrial economy at the cost of unskilled labour intensive and primary goods industries. The economy became increasingly specialized in producing products requiring use of skilled labour. The U.S.A. increased its comparative advantage in primary products category while its competitiveness in unskilled labour intensive and human capital intensive products remained stable. The most striking revelation of their study was the strategic alignment and complementary nature of the two countries' specializations in high-technology products. Japan and U.S.A. didn't follow the same learning path in the technological space. In some product categories, Japan lost its comparative advantage to the U.S.A. while in others, the U.S.A. lost its comparative advantage to Japan.

Ndayitwayeko and Ndimanya(2015) studied exports of the cash crop 'Tea' of the East African Community (EAC). Their objective was to find the degree of Comparative advantage enjoyed by EAC members in export of tea to third market and how the pattern evolved over the period of study.They used the Normalized Revealed Comparative Advantage (NRCA) introduced by Run et al. (2009) and Additive Revealed Comparative Advantage (ARCA) introduced by Hoen and Oosterhaven (2006), and a time trend regression analysis model to detect rise or fall in countries' comparative advantage in this cash crop.Their analysis showed that all EAC members, except Uganda have considerably lost their comparative advantage during the period. Burundi has been the most poorly performing country with a comparative disadvantage in this sector. Kenya, one of the largest tea producers in the world also lost its competitiveness due to rising production efficiencies of competitors, basically Sri Lanka, India and China. Ndayitwayeko, Odhiambo, Korir, Nyangweso and Chepng'eno(2014) studied the pattern of change in the revealed comparative advantage of EAC members in Coffee. With main focus on Burundi, their objective was to identify how Burundi has performed against its EAC members during the study period. They used the Normalized Revealed Comparative Advantage (Run et al., 
2009) and time trend regression analysis model to discern whether countries lost or gained competitiveness during the period under study. Their analysis reflected a gradual decline in the competitiveness in coffee exports for all EAC members. Burundi's performance was the weakest with lowest export level and NRCA. The authors suggested institutional reforms, privatization and liberalization of coffee sub-sectors to improve the quality and quantity of exports in this region, especially in Burundi.

\section{Research Design}

Data

For the purpose of the study, the series covers the data from 2001 to 2015 in case of Rwanda. The period of study chosen is based on the availability of data. Data covers 5000 entries for various product classifications.

The study is based on export data as per the HS (H-S 1996) classification. Governed by "The International Convention on the Harmonized Commodity Description and Coding System", the Harmonized Commodity Description and Coding System generally referred to as "Harmonized System" or simply "HS" is a multipurpose international product nomenclature developed by the World Customs Organization (WCO). It comprises about 5,000 commodity groups; each identified by a six digit code, arranged in a legal and logical structure and is supported by well-defined rules to achieve uniform classification. The system is used by more than 200 countries and economies as a basis for their Customs tariffs and for the collection of international trade statistics. Over $98 \%$ of the merchandise in international trade is classified in terms of the HS. The HS contributes to the harmonization of Customs and trade procedures, and the non-documentary trade data interchange in connection with such procedures, thus reducing the costs related to international trade. It is also extensively used by governments, international organizations and the private sector for many other purposes such as internal taxes, trade policies, monitoring of controlled goods, rules of origin, freight tariffs, transport statistics, price monitoring, quota controls, compilation of national accounts, and economic research and analysis. The HS is thus a universal economic language and code for goods, and an indispensable tool for international trade. Data on worldwide exports by industry are extracts from the data portal World Integrated Trade Solution (WITS), maintained by The World Bank in close collaboration with the United Nations Conference on Trade and Development (UNCTAD). The ultimate source of the exports data is the United Nation Statistical Division (UNSD) Commodity Trade (COMTRADE) database that contains exports by commodity and partner country. Values are recorded in U.S. dollars.

\section{Methodology}

The paper utilizes the measure of the index of Revealed Comparative Advantage (RCA) as introduced by Balassa (1965). The central idea to determine a country's export 'strong' sectors by analysing its actual export flows was pioneered by Liesner (1958). This procedure was refined by Bela Balassa $(1965,1989)$ to form the now popularly known 'Balassa Index'. Since the actual export flows 'reveal' the country's sectoral strength, it is also known as Revealed Comparative Advantage.

As per this measure, a country's comparative advantage is 'revealed' by the relative export performance of individual product categories to the global export performance relative to that product category. Formulaically, the Revealed Comparative Advantage is expressed as:

$$
\operatorname{RCA}_{\mathrm{ij}}=\frac{x_{i j}}{x_{w j}} / \frac{X_{i}}{X_{w}}
$$

where,

$\mathrm{RCA}_{\mathrm{ij}}=$ Revealed comparative advantage of the ith country's, jth industry,

$\mathrm{x}_{\mathrm{ij}}=$ Merchandise exports of the jth industry by the ith country,

$\mathrm{X}_{\mathrm{i}}=$ Total merchandise exports of the ith country,

$\mathrm{x}_{\mathrm{wj}}=$ World merchandise exports of the jth industry,

$\mathrm{X}_{\mathrm{w}}=$ Total merchandise world exports.

Many countries are, for example, producing and exporting cars. To establish whether a country, say Japan, holds a particularly strong position in the car industry, Balassa argued that one should compare the share of car exports in Japan's total exports with the share of car exports in a group of reference country's total exports. The Balassa index is therefore essentially a normalized export share. More specifically, if $\mathrm{BI}_{\mathrm{j}}^{\mathrm{A}}$ is country A's Balassa index for industry $\mathrm{j}$, this is defined as to:

$$
B I_{j}^{A}=\frac{\text { share ofindustry } j \text { in country A exports }}{\text { share of industry jin reference country exports }}
$$


If $\mathrm{BI}^{\mathrm{A}}>1$, country $\mathrm{A}$ is said to have a revealed comparative advantage in industry $\mathrm{j}$, since this industry is more important for country A's exports than for the exports of the reference countries i.e. If the RCA index for a particular industry is greater than 1 , it implies that the country has a revealed comparative advantage in the exports/imports of that industry and vice-versa.

As such for any particular country, Sector $i$ 's revealed comparative advantage in year $t$ is:

$$
\mathrm{RCA}_{\mathrm{i}, \mathrm{t}}=\frac{X_{i, t}^{\text {Country }} / \int_{\sum_{k} X_{k, t}^{\text {Country }}}}{X_{i, t}^{\text {World }} / \int_{\sum_{k} X_{k, t}^{\text {World }}}}
$$

The paper employs descriptive and analytical statistics to explain its objectives of measuring export competitiveness and comparative advantages in the African country.

\section{Objectives Of Study}

The study has been undertaken with the following objectives in mind:

1. To understand the pattern of exports of Rwanda

2. To identify changes in the pattern of Rwandan Exports

3. To identify the core areas of Rwanda where it specializes

\section{Analysis \& Interpretation}

The Analysis of Rwanda's RCA has been carried out at the chapter, sector and product, and subproduct level i.e. 4 Digit and 6 Digit level HS-1996 Classification. It has been done because pattern of trade may differ at different levels of disaggregation within a chapter. First of all, the top ten chapters where Rwanda has highest RCA have been studied followed by their classifications and sub classifications. Subsequently, sudden breakouts in the RCA of any chapter or its classifications have been discussed. Finally, the last part looks at the RCA in terms of types of goods traded. At the aggregate level, Rwanda enjoyed comparative advantage in 24 out of 76 chapters it exported in 2015. In the first year of study, this figure was 6 out of 32 chapter goods that the country exported. At the most dis-aggregated level, i.e. the 6-Digit level, Rwanda had comparative advantage in 189 goods in 2015. This figure was 27 in 2001. Ores, Slag and Ash (C-26) occupied the top spot in 2001 with RCA of 27.86. It has relegated to third spot in 2015 with RCA 22.2.

Table 1: Top ten products as per RCA for Rwanda

\begin{tabular}{|l|l|l|}
\hline Chapter & \multicolumn{1}{|c|}{ Chapter Name } & RCA(2015) \\
\hline $\mathbf{0 9}$ & Coffee, tea, mati and spices. & 81.46 \\
\hline $\mathbf{1 1}$ & Prod.mill.indust; malt; starches; inulin; wheat g & 42.79 \\
\hline $\mathbf{2 6}$ & Ores, slag and ash. & 22.2 \\
\hline $\mathbf{0 1}$ & Live animals & 9.3 \\
\hline $\mathbf{4 1}$ & Raw hides and skins (other than furskins) and lea & 8.58 \\
\hline $\mathbf{7 8}$ & Lead and articles thereof. & 7.25 \\
\hline $\mathbf{1 5}$ & Animal/veg fats \& oils \& their cleavage products; & 6.66 \\
\hline $\mathbf{2 5}$ & Salt; sulphur; earth \& ston; plastering mat; lime & 5.68 \\
\hline $\mathbf{1 0}$ & Cereals & 4.71 \\
\hline $\mathbf{0 7}$ & Edible vegetables and certain roots and tubers. & 2.97 \\
\hline
\end{tabular}

In 2015, Top Spot was occupied by Coffee, Tea, Mati \& Spices (C-09). This chapter held significance in earlier years too. In the late 1990s after the genocide, the Rwandan Government recognized the potential of coffee and tea as cash crops and export value products, and implemented several policies and strategies (National Coffee Strategy and National Tea Strategy) to make coffee and tea a priority sector. Through Research in better harvesting practices, farmer education, designation of more area for cultivation of these crops, better marketing opportunities, etc. Rwanda became one of the largest exporters of high quality coffee beans and Tea. In 2015, It generated over $22 \%$ of Export Revenue for the country. It has maintained its top spot in the RCA ranking since 2003. However, the RCA of Chapter 9 has fallen over the years. Increasing competition from other tea and coffee exporters made Rwandan exports uncompetitive. To counter this problem, Rwandan government focused on niche markets by catering to the needs of a handful of importing countries through marketing its coffee as one of the best qualities coffee in the world. This has helped Rwandan coffee growers fetch attractive price for their produce even amid rising volatility in world coffee markets. In case of tea, falling prices due to increased supply, loopholes in supply chain, lack of investment in research \&development, and education kept export value of Rwandan tea stagnant. In 2001, C-09 comprised of 50\% of total Exports of Rwanda. The proportion has fallen to $22.78 \%$ in 2015. The growth of Rwanda's Coffee exports (0901) has been commensurate with growth of this sub-category in the entire world. Between 2001 and 2015, export value of 
this category increased by CAGR of $10.68 \%$ while growth of Rwanda's export was marginally lower with CAGR of $10.15 \%$. Moreover, Tea (0902) world export value grew by CAGR of $6.06 \%$ while that of Rwanda grew by CAGR $9.79 \%$ during the period under review.

Other chapters in the top 10 list include Live Animals (C-01), Raw Hides and Skins (C-41), Lead and Articles thereof(C-78), Animal/Veg Fats \& oils (C-15), Salt, Sulphur, Earth \& Stone; Plastering Materials; Lime (C-25), Cereals (C-10) and Edible Vegetables and certain roots and tubers (C-07) with comparative advantage $9.3,8.59,7.25,6.66,5.68,4.71$ and 2.97 respectively. Ores, Slag and Ash $(\mathrm{C}-26)$ had the $3^{\text {rd }}$ largest RCA in 2015, but its comparative advantage has ebbed during the period under study. Mining Industry is the Rwanda's second largest export earner. Rwanda's comparative advantage lies chiefly in Tin (2609), Tungsten (2611), Niobium, Tantalum, Vanadium ores (2615). In 2006-07, Government privatized most of the mining concessions which boosted this sector's performance in terms of production and export earnings. It has been one of the most crucial sectors since the beginning of period under review. Tantalum, Vanadium ores exports have been a significant contributor in export revenue of Rwanda since 2001. The export value has fluctuated over the years, but there is an uptrend. The RCA, commensurate with export value, has fluctuated. But there is an uptrend up till 2013. In 2014 and 2015, the RCA declined due to fall in export value. Tin ores RCA has fallen from a high of 31365 in 2004 to a low of 3743 in 2014. It was 4743 in 2015. Lac, Gum, resins \& other Vegetable saps \& extracts (C-13), with RCA 14.64 in 2001, doesn't appear in the top 10 ranks in 2015. Lac; gums \& resins etc (C13) haven't been a substantial part of Rwanda's Exports ever. They accounted just $0.5 \%$ of the country's total exports in 2001. Additionally, the products under this chapter were not exported at all 2013 onwards (a few hundred $\$$ in 2013). Only 2 products under the sub-category "Vegetable saps and extracts; pectic substances, pectinates and pectates; agar-agar and other mucilages and thickeners derived from vegetable products, whether or not modified(1302)" were exported during some years before 2013.

The exports of live sheep and goats has been falling since 2012. The dominant share in this category is of Goats. Their export value has fallen from $\$ 693.49 \mathrm{~K}$ in 2012 to $\$ 67.27 \mathrm{~K}$ in 2015 . As a result, the RCA of Rwanda in this category has also witnessed a downtrend. It has fallen from a high of 20 in 2011 to as low as 1.2 in 2015. In Cereals(C-10), Rwanda enjoys comparative advantage in Rice. The country started exporting rice in 2005 and the export value has increased from \$40k Dollars in 2005 to \$16.62M in 2015. Initially, the RCA was less than 1. But since 2012 country's comparative advantage in this commodity has been greater than 1, growing from 5.35 in 2012 to 20.41 in 2015. This was the result of government's efforts to make Rwanda a selfsufficient nation in paddy by harnessing the naturally appropriate climatic conditions for paddy production, increasing the area under cultivation for paddy, and projecting the country as a potential exporter to the East African Community (EAC).

In sugar and sugar confectionery (C-17), Rwanda had comparative advantage in chewing gums (170410) for 4 consecutive years from 2012 to 2015. Incentives for setting up industries is a welcoming signal for companies to manufacture in Rwanda and this is benefitting Rwanda in the form of rising export revenue from products in this chapter. Under Chapter 15, Rwanda has been witnessing rising comparative advantage on account of increasing exports of Vegetable fats and oils and their fractions (151620). The export value continues to increase and so is the RCAI.

Under miscellaneous edible preparations (C-21), tomato ketchup (210320), active yeast (210210) and prepared baking powders (210230) had a comparative advantage in greater than 1. RCAI of tomato ketchup has increased from 22.24 in 2013 to 36.25 in 2015. Tomato is one of the primary vegetables produced in Rwanda. With government support, processing units have been set up which have increased exports of tomato pastes and ketchups lately. Under Salt; Sulphur; Earth \& Stone; Plastering Material; Lime (C-25), Rwanda enjoyed Comparative Advantage in Salt (2501), Portland, Aluminium, Slag Cement, etc. (2523). The export value of Salt (table salt and denatured) (250100) has increased remarkably over time and has been consistently growing since 2009. From $\$ 22.3 \mathrm{~K}$ in 2009 , it increased to $\$ 1.47 \mathrm{M}$ in 2015 . Consequently, the RCAI has increased from 0.51 in 2009 to 17.02 in 2015. Exports of Portland cement (252329) have also increased considerably over the last decade and hence, its RCAI has risen over this period. From export value of a mere $\$ 13.7 \mathrm{~K}$ in 2004 , it increased to over $\$ 5.15 \mathrm{M}$ in 2015. RCAI was 0.34 in 2004 which stood at 23.46 in 2015.

Over the last 3 years, the exports of unwrought lead (7801) from Rwanda have improved in value, which has had a positive effect on its comparative advantage in chapter 78. Export value was $\$ 94.3 \mathrm{~K}$ in 2013 with RCAI 0.48. It increased to $\$ 611 \mathrm{~K}$ and $\$ 1.67 \mathrm{M}$, and RCAI increased to 2.87 and 8.76 in 2014 and 2015 respectively. Under Beverages, Spirits and Vinegar (C-22), Waters, including natural and artificial mineral waters (2201), Waters, including minerals waters and aerated waters (2203) and Beers made from Malt (2203) have had comparative advantage for past few years. Export value of sub-chapter 2201 has increased consistently. Its comparative advantage though, has remained relatively stable over time. It ranged between 1-5 during 2010 and 2015. Sub-Chapters 2202 and 2203 give a mixed picture. Export value of beer from malt (2202) increased from 2005 till 2008, then decreased in 2009. It started to increase from 2009 until it fell again 
in 2014 and further in 2015. Its RCAI resonate the same volatility. The trend of sub-chapter 2203 shows the same volatility in both export value and RCAI.

Products under Works of Art; Collectors' pieces and antiques (C-97) have always been a miniscule part of Rwanda's Exports. However, the country's comparative advantage in this chapter's products had been greater than 1 during some part of the study. Original Sculptures and Statuary, in any material (9703) have been the most significant component of this chapter for Rwanda since 2001. Its RCAI index peaked at 11.2 in 2007 when export value was $\$ 365 \mathrm{~K}$. Since then, the export value and consequently, the RCAI reveal a downtrend in this sub-chapter. Only in 2015 did the RCAI increased to 1.86. Rwanda Exported $\$ 1.39 \mathrm{M}$ worth of Paintings, Drawings and Pastels, executed completely (9701) in 2008 and its RCAI was 3.7. But the advantage couldn't be maintained for long as export value declined and RCAI turned less than 1 in 2011. Collectively, the country enjoyed comparative advantage in this chapter until 2010. Under Chapter 27-Mineral fuels, oils and products of their distillation; Bituminous substances; mineral waxes- formed 67\% of Rwanda's total Exports in 2001. As the economy grew and variety of products traded expanded, products of this chapter started to assume lesser importance for the economy. Petroleum oils and oils obtained from bituminous minerals (excluding crude); preparations containing $>=70 \%$ by weight of petroleum oils or of oils obtained from bituminous minerals, these oils being the basic constituents of the preparations, n.e.s.; waste oils containing mainly petroleum or bituminous minerals (2710) form the greatest portion of this chapter in Rwanda. Since 2009, the RCAI of this 4digit Code has been increasing steadily and turned advantageous in 2012. It stood at 4.08 in 2015. In 2015, the export value of this sub-chapter was $\$ 86.23 \mathrm{M}$ and it formed $14.9 \%$ of total export value.

\section{Conclusion \& Recommendations}

A detailed analysis was conducted of the Rwanda's export competitiveness both at the aggregated and dis-aggregated level. From the analysis and interpretation, it is safe to say that Rwandan economy has grown and expanded during this period. New products have started to be produced and exported. This is evident from the fact that primary pillars of the country's export, i.e. Coffee, tea, different ores and minerals, Raw hides and skins have been growing in value but their proportion in total export value have been falling. A pro-active approach of the government to turn Rwanda into a manufacturing hub for various types of goods, both semiprocessed and processed is paying off. However, a downward trend in the RCA value for most of its primary exports is a signal that the country's competitiveness in their production is fading. This is happening due to technological, physical and financial constraints. Its agrarian status offers it a large opportunity to invest in agroprocessing industry. The country produces such agricultural goods, which, if processed and converted into high value goods, can boost country's position in global value chain and help it tap a wider international market base.

Amid growing uncertainty in the global market, increasing volatility in prices of agricultural and commercial commodities which are governed by international market forces, it is essential for a country like Rwanda to portray itself as a brand to the world. Branding can help Rwanda minimize the negative impacts of price volatilities and minimize the risk of global uncertainty. This can happen only through setting up of a strong industrial base in the country for manufacturing those goods whose raw material requirement can be filled by indigenously produced goods, basically agricultural goods. The country needs to reduce its dependence on commodities which have sustained it since the beginning. A boost in industrial sector would lead to more employment opportunities and expansion in the services sector as well, eventually shifting its economy to an industrial or service economy status. Investment in Research \& Development and education would be crucial for the country to enhance the skills and competencies of its labour. Overall, Rwanda shows bright signs of becoming an export oriented economy with comparative advantage in semi-processed and processed goods.

\section{References}

[1] Balassa, B. \&. (1989). "Revealed" Comparative Advantage in Japan and the United States. Journal of International Economic Integration, 4(2), 8-22. Retrieved from http://www.jstor.org/stable/23000034

[2] Balassa, B. (1965). Trade Liberalisation and "Revealed" Comparative Advantage. The Manchester School of Economics and Social Sciences, 33(2), 99-123. doi:10.1111/j.1467-9957.1965.tb00050.x

[3] Data: Export of Goods and Services. (n.d.). Retrieved February 23, 2017, from data.worldbank.org: http://data.worldbank.org/indicator/NE.EXP.GNFS.CD

[4] Data: Exports of goods and services (\% of GDP). (n.d.). Retrieved February 23, 2017, from data.worldbank.org: http://data.worldbank.org/indicator/NE.EXP.GNFS.ZS

[5] Dictionary.com Unabridged. (n.d.). Retrieved February 23, 2017, from Dictionary.com: http://www.dictionary.com/browse/trade

[6] Export Commodities. (n.d.). Retrieved January 2017, from National Agricultural Export Development Board: http://www.naeb.gov.rw

[7] International Trade Statistics. (n.d.). (I. T. Centre, Producer) Retrieved January 2017, from Trade Map: http://www.trademap.org

[8] Jaravaza, D. C. (2013, January 7). Rwanda: What Drives the Nation in International Trade? International Journal of Management Sciences and Business Research, 2(6).

[9] (2015). Key Statistics and Trends in International Trade. UNCTAD. United Nations Publication.

[10] Laursen, K. (2000). Do Export and Technological Specialisation Patterns Co-evolve in Terms of Convergence or Divergence?: Evidence from 19 OECD Countries, 1971-1991. Journal of Evolutionary Economics, 10(4), 415-436. doi:doi: $10.1007 / \mathrm{s} 001910000044$ 
[11] Library: The World Factbook. (n.d.). Retrieved February 19, 2017, from Central Intelligence Agency: https://www.cia.gov/library/publications/the-world-factbook/geos/rw.html

[12] Ndimanya, W.-M. N. (2015). Dynamics of Tea Trade Competitiveness in EAC: Evidence from Tea Exports of Burundi. Journal of Economics and Sustainable Development, 6(12), 154-160.

[13] Ricardo, D. (1817). The Principles of Political Economy and Taxation. John Murray.

[14] Rwanda: Economy \& Industry. (n.d.). Retrieved January 2017, from Our Africa: http://www.our-africa.org/rwanda/economyindustry

[15] Smith, A. (1776). The Wealth of Nations. W. Strahan and T. Cadell, London.

[16] Sukati, M. (2016, March 11). COMESA's Revealed Comparative Advantage in Common Agricultural Commodities. Retrieved from https://mpra.ub.uni-muenchen.de/69989/

[17] W.M. Ndayitwayeko, M. O. (2014). Comparative Advantage of the Eastern and Central Africa in the Coffee Export Sector: The Case of Burundi. African Crop Science Journal, 22(4), 987-995. 